\title{
Utility of Flexible Ureterorenoscopy and Laser Lithotripsy in the Treatment of Multiple Intrarenal Stones
}

\section{Multipl Böbrek Taşlarında Fleksibl Üreterorenoskopi ve Lazer Litotripsinin Etkinliği}

\author{
Hasan Yılmaz', Ali Sarıbacak ${ }^{2}$ \\ ${ }^{1}$ Kocaeli University Faculty of Medicine, Department of Urology, Kocaeli, Turkiye \\ ${ }^{2}$ VM Medical Park Kocaeli Hospital, Clinic of Urology, Kocaeli, Turkiye
}

\section{What's known on the subject? and What does the study add?}

Only a few reports have described ureteroscopic treatment of multiple intrarenal stones. Extracorporeal shock wave lithotripsy and percutaneous nephrolithotomy have some disadvantages with multiple intrarenal stones. The present study showed that flexible ureterorenoscopy with laser lithotripsy was an effective and safe treatment option in patients with multiple intrarenal stones.

\begin{abstract}
Objective: We aimed to determine the safety and efficacy of flexible ureterorenoscopy and Holmium laser lithotripsy in treating multiple intrarenal stones. Materials and Methods: We identified 32 consecutive patients with multiple intrarenal stones who underwent flexible ureterorenoscopy and/or laser lithotripsy performed by a single surgeon. Informed consent was obtained from all participants before treatment. Each patient was evaluated in terms of stone location, stone number, stone size, stone burden (cumulative stone length), body mass index, operative time, stone-free rate, and perioperative complications.

Results: The median age of the patients was 38 years [interquartile range (IOR), 34.25-52.00]. The patients had a total of 75 intrarenal calculi. The average number of stones per patient was 2.50 (IOR, 2.0-3.0). The median total stone burden per patient was $23.0 \mathrm{~mm}$ (IQR, 19.0-28.0 mm). Twenty-one patients (65.5\%) had stone burdens $>20 \mathrm{~mm}$, and $11(34.5 \%)$ had burdens $\leq 20 \mathrm{~mm}$. The overall final stone-free rate was $78.1 \%$. The stone-free rates for patients with stone burdens $\leq 20 \mathrm{~mm}$ and $>20 \mathrm{~mm}$ were $81.8 \%$ (9/11) and 76.2\% (16/21), respectively ( $p=0.544)$. A perioperative complication (urinary leakage) occurred in one patient. Postoperative complications were recorded in four (12.5\%) patients; a urinary tract infection in one, pain requiring parenteral medication in two, and hematuria in one.

Conclusion: Flexible ureterorenoscopy combined with laser lithotripsy may be an effective treatment option for patients with multiple intrarenal stones; we noted only a few minor complications. The success rate was higher in patients with stone burdens $\leq 20 \mathrm{~mm}$.
\end{abstract}

Keywords: Flexible ureterorenoscopy, laser lithotripsy, multiple renal stones

$\ddot{0 z z}$

Amaç: Multipl böbrek taşlarının tedavisinde fleksibl üreterorenoskopi ile birlikte Holmium lazer kullanımını etkinlik ve güvenlik açıından değerlendirmeyi amaçladık.

Gereç ve Yöntem: Kliniğimizde multipl böbrek taşı nedeni ile tek cerrah tarafından fleksibl üreterorenoskopi ve lazer litotripsi yapılan 32 hasta retrospektif olarak değerlendirildi. Hastaların yaşı, cinsiyeti, vücut kitle indeksi, operasyon süresi, taşlarının yeri, boyutu, sayısı, yükü, taşsızık oranı ve komplikasyonlar kaydedildi. Taş yükü böbrek içindeki taşların uzunlukları toplamı olarak hesaplandı. Taşsızlık, operasyon sonrası 3. ayda taş olmaması veya böbrek içinde $<3 \mathrm{~mm}$ taş olması olarak değerlendirildi.

Bulgular: Ortanca hasta yaşı 38 [çeyrekler arası aralık (IQR), 34,25-52,00] yıl idi. Hastalarda toplam 75 intrarenal taş vardı. Hasta başı ortanca taş sayısı ve taş yükü sırasıyla 2,50 (IOR, 2,0-3,0) 50 ve 23,0 mm (IOR, 19,0-28,0 mm) idi. Hastaların 21'inde $(\% 65,5)$ taş yükü >20 mm iken 11 (\%34,5) hastanın $\leq 20 \mathrm{~mm}$ idi. Toplam taşsızlık oranı \%78,1 idi. Bu oran taş yükü $\leq 20 \mathrm{~mm}$ ve $>20 \mathrm{~mm}$ olan hastalarda sırasıyla \%81,8 (9/11) ve \%76,2 (16/21) idi $(p=0,544)$. Bir hastada operasyon sırasında idrar kaçağına neden olan üreter perforasyonu gelişti, double-J kateter ile tedavi edildi. Dört hastada $(\% 12,5)$ postoperatif komplikasyon izlendi (iki hasta paranteral tedavi gerektirecek ağrı, bir hastada hematüri, bir hastada ise idrar yolu enfeksiyonu).

Correspondence: Ali Sarıbacak MD, VM Medical Park Kocaeli Hospital, Clinic of Urology, Kocaeli, Turkiye Phone: +90 2628883829 E-mail: saribacak@gmail.com ORCID-ID: orcid.org/0000-0001-5670-4822 Received: 23.03.2017 Accepted: 08.08.2017

Cite this article as: Yılmaz H, Sarıbacak A. Utility of Flexible Ureterorenoscopy and Laser Lithotripsy in the Treatment of Multiple Intrarenal Stones. J Urol Surg 2017;4:129-133.

๑Copyright 2017 by the Association of Urological Surgery / Journal of Urological Surgery published by Galenos Publishing House. 


\section{Öz}

Sonuç: Böbrek içi multipl taş tedavisinde fleksibl üreterorenoskopi ile birlikte lazer litotripsi düşük komplikasyon oranı ve yüksek başarıya sahiptir. Bu taşların tedavisinde ilk tercih kullanılabilmesi için ileri dönük kör karşılaştırmalı çalışmalara ihtiyaç vardır.

Anahtar Kelimeler: Fleksibl üreterorenoskopi, lazer litotripsi, multipl böbrek taşları

\section{Introduction}

Huffman et al. (1) were the first to perform retrograde intrarenal surgery (RIRS) in 1983. They used a rigid ureteroscope to deliver ultrasonic lithotripsy to a pelvic stone. Since that time, flexible ureteroscopes have been developed and the Holmium laser has been used for fragmentation. The advances in endoscopic imaging technology include enhanced deflection ability, increased durability, and reductions in diameter. Thus, the role played by RIRS in stone surgery has expanded.

The European Association of Urology guidelines on urolithiasis recommend different treatment modalities according to renal stone size and location (2). Thus, the recommended first-line treatment for renal stones $>20 \mathrm{~mm}$ in diameter is percutaneous nephrolithotomy (PCNL), and both extracorporeal shock wave lithotripsy (ESWL) and endourology (RIRS and PCNL) for renal stones $10-20 \mathrm{~mm}$ in diameter. While ESWL is not recommended as the first-line treatment for lower pole renal stones in the presence of unfavourable factors, RIRS is strongly recommended (2). Nevertheless, there is no clear recommendation for multiple renal stones. In the treatment of these stones, because flexible ureterorenoscopy can readily reach different calices, it may have a higher success rate, especially for multiple stones in different locations. With PCNL and ESWL, there is also a need for multiple interventions for multiple renal stones in different locations. Although only a few studies have evaluated RIRS for the treatment of multiple renal stones, they have reported low interventions with high success rates $(3,4,5,6,7)$.

In the present study, we sought to determine the safety and efficacy of flexible ureterorenoscopy and Holmium laser lithotripsy in treating multiple renal stones.

\section{Materials and Methods}

We retrospectively reviewed data on nephrolithiasis patients treated in our institution (Izmit Konak Hospital) from July 2013 to April 2015. We identified 32 consecutive patients with multiple intrarenal stones who underwent flexible ureterorenoscopy and laser lithotripsy performed by a single surgeon. All patients were informed about other treatment modalities such as PCNL and ESWL. Flexible ureterorenoscopy was performed based on patient preferences. Informed consent was obtained from all participants before treatment. All patients were evaluated prior to treatment by computed tomography (CT) running a dedicated stone protocol.
Each patient was evaluated in terms of stone location, stone number, stone size, stone burden (cumulative stone length), body mass index (BMI), operative time, stone-free rate (SFR), and perioperative complications. The total stone burden was the sum of all stone diameters $(3,6,8)$. Preoperative urinalyses and cultures were performed and appropriate antibiotics were prescribed if necessary. Operations were delayed in such cases. The operation time was defined as the time between commencement of endoscopy and placement of the double-J stent. Stone-free status was defined as the absence of stone fragments other than asymptomatic, insignificant residual fragments $<3 \mathrm{~mm}$ in diameter.

\section{Technique}

Each patient was placed in the dorsal lithotomy position under general anaesthesia, and intravenous antibiotics were commenced. First, ureteroscopy was performed using an 8-9.5F semi-rigid ureteroscope (Karl Storz, Germany) guided by a $0.038 \mathrm{~mm}$ diameter guidewire. The ureter was evaluated in terms of pathologies (stones, obstructions, and so forth) and subjected to dilation before placement of an access sheath [9.5/11.5, 11.0/13.0, 12.0/14.0-F (Cook, Boston Scientific)] to allow optimal visualisation, maintaining a low intrarenal pressure, and facilitating extraction of stone fragments. If an access sheath could not be placed, a double-J stent was placed and the operation was re-scheduled for 2 weeks later (passive dilation). A 7.2-F flexible ureteroscope (Storz FLEX-X2, Germany) through which a $270 \mu \mathrm{m}$ laser fibre was used for treatment. The Holmium laser energy was set to $0.4-1.2 \mathrm{~J}$ delivered at $5-12 \mathrm{~Hz}$ (Dornier $20 \mathrm{~W}$ Laser, Germany). In cases of large stones $(>1 \mathrm{~cm})$, we prefer low frequency and high power to fragment and collect the parts. In the case of small stones, we prefer high frequency and low power to dust it. We used 2.2-F tipless nitinol baskets (NCircle, Ngage, Cook Medical, Limerick, Ireland) for retrieval of stone fragments $>2 \mathrm{~mm}$ in diameter. Postoperatively, a 6-F $26 \mathrm{~cm}$ long double-J stent was placed based on the surgeon's preference. This stent was removed under local anaesthesia, using a flexible or rigid cystoscope, within 3 weeks postoperatively. Residual fragment status was assessed via non-contrast CT, or renal ultrasonography (US) plus a plain frontal supine radiograph of the kidneys, ureters, and bladder (KUB) (only patients with radiopaque stones), 3 months after removal of the double-J stent.

\section{Statistical Analysis}

Statistical analyses were performed with the SPSS for Windows software (version 21.0; SPSS, Inc., Chicago, Illinois). Mean and 
standard deviations were calculated for normally distributed numerical data, while median and interquartile ranges (IORs) were obtained for numerical data with skewed distributions. The Pearson $\chi^{2}$ test and Fisher's exact test were used to compare SFRs. The Mann-Whitney U test was used to compare operation times. A $p$ value of $<0.05$ was taken to indicate statistical significance.

\section{Results}

On retrospective analysis, there were 32 patients: Twenty-four males and eight females. The median age was 38.00 years (IOR, 34.25-52.00) (Table 1). As regarding the weight of the patients, eight had normal weight (BMI: 18.50-24.99 $\mathrm{kg} / \mathrm{m}^{2}$ ), 13 patients were overweight (BMI: $25.00-29.99 \mathrm{~kg} / \mathrm{m}^{2}$ ) while 13 patients were obese $\left(\mathrm{BMI} \geq 30.00 \mathrm{~kg} / \mathrm{m}^{2}\right)$. The patient stone demographics are shown in Table 2. There were a total of 75 intrarenal calculi. The median stone number per patients was 2.50 (IQR, 2.0-3.0). The median total stone burden per patient was 23.0 (IQR, 19.028.0). Twenty-one patients $(65.5 \%)$ had a stone burden $>20$ $\mathrm{mm}$, and 11 patients (34.5\%) had a stone burden $\leq 20 \mathrm{~mm}$.

Evaluation of intraoperative and postoperative data is shown in Table 3. Passive dilatation with double-J stent was applied

\section{Table 1. Patient characteristics}

\begin{tabular}{ll}
\hline Number of patients $(\mathbf{n})$ & $\mathbf{3 2}$ \\
\hline Gender & $24(75 \%)$ \\
Male, $\mathrm{n}(\%)$ & $12(25 \%)$ \\
Female, $\mathrm{n}(\%)$ & $38(34.25-52.00)$ \\
Age, $[$ median $(\mathrm{IOR})]$ & $28(26.00-31.75)$ \\
Body mass index $\left(\mathrm{kg} / \mathrm{m}^{2}\right)[$ median $(\mathrm{IOR})]$ & \\
\hline IQR: Interquartile range & \\
\hline
\end{tabular}

Table 2. The stone demographics

\begin{tabular}{ll}
\hline Stone laterality & \\
\hline Right, $\mathrm{n}(\%)$ & $13(40.6 \%)$ \\
Left, $\mathrm{n}(\%)$ & $18(56.3 \%)$ \\
Bilaterally, $\mathrm{n}(\%)$ & \\
Stone location & $23(71.9 \%)$ \\
Renal pelvis, $\mathrm{n}(\%)$ & $28(87.5 \%)$ \\
Lower pole, $\mathrm{n}(\%)$ & $15(46.9 \%)$ \\
Mid-pole, $\mathrm{n}(\%)$ & $8(25.0 \%)$ \\
Upper pole, $\mathrm{n}(\%)$ & $2.50(2.0-3.0)$ \\
Number of stones per patients (n), median (IOR) \\
Total stone burden per patients (mm), median \\
(IOR) $23.0(19.0-28.0)$ \\
\hline IQR: Interquartile range & \\
\hline
\end{tabular}

in three patients (access sheath application error). The overall median operation time was 67.50 minutes (IQR 60.00-80.00). Operation time was significantly longer in patients with stone burden $>20 \mathrm{~mm}$ [76.52 (IQR 60.00-85.00) minute] compared to those with $\leq 20 \mathrm{~mm}$ [60.00 (IOR 40.00-60.00) minute] ( $p=0.026$ ). The overall SFR was $78.1 \%$. SFRs for patients with a stone burden $\leq 20 \mathrm{~mm}$ and $>20 \mathrm{~mm}$ were $81.8 \%(9 / 11)$ and $76.2 \%(16 / 21)$, respectively $(p=0.544)$. Significant residual fragments $(\geq 3 \mathrm{~mm})$ were found in seven patients. The total stone burden was $>20$ $\mathrm{mm}$ in these five patients, while $\leq 20 \mathrm{~mm}$ in two patients (one with a history of open renal surgery).

Perioperative complication (urinary leakage) was occurred in one patient with a 20-mm stone burden. He was treated with only a double-J stent. A follow-up CT scan at 1 month after double-J removal showed ureteral healing without any complication. Postoperative complications were recorded in four (12.5\%) patients (two had $\leq 20 \mathrm{~mm}$ and two had $>20 \mathrm{~mm}$ stone burden), including urinary tract infection in one, pain with requiring parenteral medication in two, and hematuria in one patients, respectively. The patient with urinary tract infection was admitted to the hospital for intravenous antibiotics. He was discharged home after $48 \mathrm{~h}$ and fully recovered in 15 days.

\section{Discussion}

Intrarenal stones are treated with ESWL, PCNL, or RIRS depending on stone size and location $(2,9)$. However, no consensus on the management of multiple intrarenal stones has yet emerged. The optimum approach must be associated with minor morbidity and a minimal need for recurring intervention.

Both ESWL and endourology are recommended first-line treatment options for renal stones $<20 \mathrm{~mm}$ in diameter (2). However, EWSL SFRs are significantly decreased under the following circumstances: shock-wave-resistant stones (formed

Table 3. Evaluation of intraoperative and postoperative data

\begin{tabular}{ll}
\hline Operation time (minutes), median (IOR) & $67.50(60.00-80.00)$ \\
Passive dilatation, n (\%) & $3(9.4 \%)$ \\
Use rate of access sheath, n (\%) & $31(96.9 \%)$ \\
Hospitalisation time (hours), median (IOR) & $24.00(22.00-24.00)$ \\
Peroperative complication, n (\%) & $1(3.1 \%)$ \\
Postoperative double-J catheterization, n (\%) & $29(90.6 \%)$ \\
Postoperative complication, n (\%) & $4(12.5 \%)$ \\
Stone free rate (overall), n (\%) & $25(78.1 \%)$ \\
Stone free rate ( $\leq 20 \mathrm{~mm}), \mathrm{n}(\%)$ & $9(81.8 \%)$ \\
Stone free rate (>20 mm), n (\%) & $16(76.2 \%)$ \\
\hline IQR: Interquartile range &
\end{tabular}


of calcium oxalate monohydrate, brushite, or cystine); the presence of a steep infundibular-pelvic angle; the presence of a long lower pole calyx $(>10 \mathrm{~mm})$; and the presence of a narrow infundibulum $(<5 \mathrm{~mm})(2)$. The ESWL SFRs fell as the BMI increased (2). In the current study, 13 (40\%) patients were overweight and 13 (40\%) were obese; the SFR was $>78 \%$. ESWL is contraindicated in pregnant patients and in those with bleeding disorders. In addition, no more than 3-5 sessions of EWSL should be conducted (2). Furthermore, ESWL often requires multiple sessions (e.g., in patients with steinstreise formations) and is associated with longer treatment periods than are other surgical methods in patients with multiple stones $(10,11)$. ESWL is associated with higher rates of residual fragment regrowth $(21-59 \%)(12,13)$ and dysrhythmia $(11-59 \%)$ $(12,14)$. Consequently, there is a need for alternative treatments for patients with multiple renal stones.

PCNL, the first-line treatment for stones $>20 \mathrm{~mm}$ in diameter, affords very high SFRs (2). However, the presence of multiple, but separated, kidney stones usually require repeat access or re-operation, and possibly also adjunctive (i.e., endourological) procedures. The most common postoperative complications are fever, bleeding, urinary leakage, and difficulties attributable to residual stones (2). Seitz et al. (15) showed that after PCNL, Clavien 1 complications (deviations from the normal postoperative course without the need for pharmacological treatment or an intervention) occurred in up to $88.1 \%$ of patients. Clavien 2 complications (including a need for blood transfusion and/or parenteral nutrition) occurred in 7\% of patients. Clavien 3 complications (requiring re-intervention) developed in $4.1 \%$ of patients. Clavien 4 complications (lifethreatening) developed in $0.6 \%$ of patients, and Clavien 5 complications (death) developed in $0.04 \%$ (15). The risks of these complications increased when procedures were repeated. De et al. (16) conducted a systematic review and meta-analysis comparing PCNL with RIRS. PCNL afforded significantly higher SFRs but was associated with more complications and a greater postoperative decrease in hemoglobin level. RIRS yielded a significantly higher SFR than micro-PCNL but a lower SFR than standard PCNL (16).

Currently, RIRS is increasingly used in patients with advanced indications. Only a few reports have described ureteroscopic treatment of multiple intrarenal stones $(3,4,5,6,7)$. Breda et al. (3) evaluated 51 patients with multiple intrarenal stones [a total of 161 intrarenal calculi, mean number of stones/patient $3.1 \pm 1$ (2-6), stone burden $21 \pm 6 \mathrm{~mm}$ ]. The overall SFRs after one and two procedures were $64.7 \%$ and $92.2 \%$, respectively. The SFRs for patients with stone burdens $>20 \mathrm{~mm}$ and $<20 \mathrm{~mm}$ were $85.1 \%$ and $100 \%$, respectively. Two operative complications developed, one major (sepsis) and four minor (3). HerreraGonzalez et al. (4) evaluated 125 patients, and the SFR after a single RIRS procedure was 74.4\%. Takazawa et al. (5) studied 51 patients (with a total of 146 stones, 37 unilateral and 14 bilateral) who underwent 65 ureteroscopic procedures. The SFR after a single session was $80 \%(41 / 51)$. In patients with stone burdens $<20 \mathrm{~mm}$ and $\geq 20 \mathrm{~mm}$, the single-session SFRs were $92 \%$ (23/25) and 69\% (18/26), respectively. No major intraoperative problems were noted (5). Alkan et al. (6) evaluated 41 patients [173 intrarenal stones; mean number of stones/patient 3.6 \pm 3.0 ; mean stone burden $22.2 \pm 8.4 \mathrm{~mm}(12-45 \mathrm{~mm})]$. The overall SFR was $91.7 \%$. The SFRs for patients with stone burdens $<20 \mathrm{~mm}$ and $>20 \mathrm{~mm}$ were $100 \%(23 / 23)$ and $84 \%$ (21/25), respectively. Minor complications developed in six patients, but no major complications were noted (6). In the present study, we evaluated the RIRS success rates in patients with multiple intrarenal stones who underwent a single procedure. Similar to the cited studies, the overall SFR was $78.1 \%$. When the patients were divided into those with stone burdens $\leq 20 \mathrm{~mm}$ and $>20 \mathrm{~mm}$, the SFRs were $81.8 \%$ and $76.2 \%$, respectively. The overall SFR for a single procedure was higher than in studies by Breda et al. (3) and Herrera-Gonzalez et al. (4), similar to that by Takazawa et al. (5), and lower than in that by Alkan et al. (6), as described above. However, the SFR of the patients with stone burden $\leq 20 \mathrm{~mm}$ seemed to be lower versus the cited studies. Most of these studies did not state the number of sessions when they divided patients according to stone burden. Thus, it is expected that the very high SFRs in patients with stone burden $<20 \mathrm{~mm}$ were probably caused by multiple procedures. Urinary system anatomies and stone localizations are also possible factors contributing to the lower SFRs.

In the present study, we encountered five minor complications (one operative and four postoperative). These were not correlated with increasing stone size. The numbers of postoperative complications were the same both in patients with stone burden $\leq 20 \mathrm{~mm}(\mathrm{n}=2)$ and those with stone burden $>20 \mathrm{~mm}$ $(n=2)$. Additionally, a perioperative complication was seen in one patient with a stone burden $\leq 20 \mathrm{~mm}$. The mean operation time was significantly higher with total stone burden $>20 \mathrm{~mm}$, as expected.

\section{Study Limitations}

The present study had some limitations. First, the retrospective nature of the study is important. In addition, there was no control group. Thus, further comparative, prospective studies are needed to draw final conclusions. Later, we evaluated residual fragment status via non-contrast CT or US plus KUB. We preferred US plus KUB in patients with radiopaque stones, because this avoided redundant exposure to $\mathrm{X}$-rays from the CT scan. This may have caused insignificant measurement variability with respect to residual stones, due to the difference in accuracy between these imaging methods. Third, it is known that the SFRs of stone retrieval techniques show variability 
according to the localization of the stone in the kidney. Thus, it would be better to compare SFRs with fixed locations and fixed stone burdens.

The total stone burden is calculated by several methods (cumulative diameter, surface area, and volume). In clinical practice, the most widely used parameter is cumulative diameter $(3,6,8)$, as in the present study. However, since this parameter does not show stone width or depth, stone volume has been proposed to be a more reliable method for confirming stonefree status. Ito et al. (17) retrospectively analyzed 243 patients with radiopaque renal stones. They measured the preoperative stone burden according to both cumulative diameter $(\mathrm{mm}$, $\mathrm{KUB})$ and stone volume $\left(\mathrm{mm}^{3}\right.$, non-contrast CT). They obtained a plain KUB film on postoperative day 1 in all cases to assess the presence of stones. They defined stone-free status as no detectable stone on KUB images. SFRs at postoperative day 1 after URS were 79.43\% (<20 mm stones) and 29.4\% ( $\geq 20 \mathrm{~mm}$ stones). They found that cumulative stone burden calculated according to stone volume was more predictive of the presence of stones on postoperative day 1 on plain KUB versus the cumulative stone diameter, especially for stones $\geq 20 \mathrm{~mm}$. However, this was a retrospective observational study. The SFR was much lower in stones of $\geq 20 \mathrm{~mm}$ compared with $<20 \mathrm{~mm}$ stones. Postoperative day 1 is a very important time point for assessing the real stone-free status.

\section{Conclusion}

In conclusion, we found that flexible ureterorenoscopy with laser lithotripsy was an effective treatment option in patients with multiple intrarenal stones; only a few minor complications were encountered. The success rates were higher in patients with stone burdens $<20 \mathrm{~mm}$. Randomised comparative studies are needed before flexible ureterorenoscopy can be recommended as a first-line treatment for multiple intrarenal stones.

\section{Ethics}

Ethics Committee Approval: This article is based on a retrospective study. All data were collected from the hospital record system, and the study was performed in accordance with the ethical standard laid down in the 1964 Declaration of Helsinki and its later amendments.

Informed Consent: Informed consent was obtained from all participants before treatment.

Peer-review: Externally peer-reviewed.

\section{Authorship Contributions}

Surgical and Medical Practices: A.S., Concept: A.S., H.Y., Design: A.S., H.Y., Data Collection or Processing: A.S., H.Y., Analysis or Interpretation: H.Y., Literature Search: A.S., H.Y., Writing: A.S., H.Y.
Conflict of Interest: No conflict of interest was declared by the authors.

Financial Disclosure: The authors declared that this study received no financial support.

\section{References}

1. Huffman JL, Bagley DH, Lyon ES. Extending cystoscopic techniques into the ureter and renal pelvis. Experience with ureteroscopy and pyeloscopy. JAMA1983;250:2002-2005.

2. Türk CPA, Sarica K, Seitz C, Skolarikos A, Straub M, Knoll T. European Association of Urology (EAU) guidelines for Interventional Treatment for Urolithiasis. Arnhem-the Netherlands: EAU Guidelines Office; 2016.

3. Breda A, Ogunyemi O, Leppert JT, Schulam PG. Flexible ureteroscopy and laser lithotripsy for multiple unilateral intrarenal stones. Eur Urol 2009;55:1190-1196.

4. Herrera-Gonzalez G, Netsch C, Oberhagemann K, Bach T, Gross AJ. Effectiveness of single flexible ureteroscopy for multiple renal calculi. J Endourol 2011;25:431-435.

5. Takazawa R, Kitayama S, Tsujii T. Single-session ureteroscopy with holmium laser lithotripsy for multiple stones. Int J Urology 2012;19:1118-1121.

6. Alkan E, Ozkanli O, Avci E, Turan M, Basar MM, Acar 0, Balbay MD. Effectiveness of Flexible Ureterorenoscopy and Laser Lithotripsy for Multiple Unilateral Intrarenal Stones Smaller Than 2 cm. Adv Urol 2014;2014:314954.

7. Alkan E, Avci E, Ozkanli A0, Acar O, Balbay MD. Same-session bilateral retrograde intrarenal surgery for upper urinary system stones: safety and efficacy. J Endourol 2014;28:757-762.

8. Mishra DK, Agrawal MS. Use of a Novel Flexible Mini-nephroscope in Minimally Invasive Percutaneous Nephrolithotomy. Urology 2017;103:5962.

9. Preminger GM, Tiselius HG, Assimos DG, Alken P, Buck C, Gallucci M, Knoll T, Lingeman JE, Nakada SY, Pearle MS, Sarica K, Türk C, Wolf JS Jr; EAU/ AUA Nephrolithiasis Guideline Panel. 2007 guideline for the management of ureteral calculi. J Urol 2007;178:2418-2434.

10. Argyropoulos AN, Tolley DA. Evaluation of outcome following lithotripsy. Curr Opin Urol 2010;20:154-158.

11. Pearle MS, Lingeman JE, Leveillee $R$, Kuo $R$, Preminger GM, Nadler RB, Macaluso J, Monga M, Kumar U, Dushinski J, Albala DM, Wolf JS Jr, Assimos D, Fabrizio M, Munch LC, Nakada SY, Auge B, Honey J, Ogan K, Pattaras J, McDougall EM, Averch TD, Turk T, Pietrow P, Watkins S. Prospective, randomized trial comparing shock wave lithotripsy and ureteroscopy for lower pole caliceal calculi $1 \mathrm{~cm}$ or less. J Urol 2005;173:2005-2009.

12. Skolarikos A, Alivizatos $G$, de la Rosette J. Extracorporeal shock wave lithotripsy 25 years later: complications and their prevention. Eur Urol 2006;50:981-990.

13. Osman MM, Alfano $Y$, Kamp S, Haecker A, Alken P, Michel MS, Knoll T. 5-year-follow-up of patients with clinically insignificant residual fragments after extracorporeal shockwave lithotripsy. Eur Urol 2005;47:860-864.

14. Zanetti G, Ostini F, Montanari E, Russo R, Elena A, Trinchieri A, Pisani E. Cardiac dysrhythmias induced by extracorporeal shockwave lithotripsy. J Endourol 1999;13:409-412.

15. Seitz C, Desai M, Hacker A, Hakenberg OW, Liatsikos E, Nagele U, Tolley D. Incidence, prevention, and management of complications following percutaneous nephrolitholapaxy. Eur Urol 2012;61:146-158.

16. De $\mathrm{S}$, Autorino R, Kim FJ, Zargar H, Laydner H, Balsamo R, Torricelli FC, Di Palma C, Molina WR, Monga M, De Sio M. Percutaneous nephrolithotomy versus retrograde intrarenal surgery: a systematic review and meta-analysis. Eur Urol 2015;67:125-137.

17. Ito $H$, Kawahara $T$, Terao $H$, Ogawa $T$, Yao M, Kubota $Y$, Matsuzaki J. Utility and limitation of cumulative stone diameter in predicting urinary stone burden at flexible ureteroscopy with holmium laser lithotripsy: a singlecenter experience. PloS One 2013;8:65060. 